\title{
ALEKSANDAR DEROKO: \\ REBUILDING SMEDEREVO AFTER 5 JUNE 1941 EXPLOSION
}

A B S T R A C T

Aleksandar Deroko had a noteworthy and decisive impact on the architectural culture of Smederevo. This paper will not treat the issue of his exceptional work on evaluating and protecting the medieval Smederevo Fortress, but rather it will focus on a very specific period during which Deroko, as an architect, set up a significant number of parameters for a new vision for Smederevo's urban culture. This vision is embodied in his projects and architectural realisations in one of the most delicate periods of the town's history, during its reconstruction that lasted a few years after a horrific wartime explosion nearly wiped Smederevo off the map, on 5 June 1941. In spite of many different ideological and political reasons, a comprehensive historical and monographic assessment of Deroko's works in Smederevo had not been made to this date. This paper will assess subjects such as Deroko's relationship with the city's historical and cultural heritage, political and ethical qualities of this relationship during a delicate period in Serbian history, and architectural and aesthetic principles that affected the way Deroko would shape his work in Smederevo and his vision for a rebuilt city. Lastly, this paper will hint at the qualifications of his work in Smederevo and its impact on the present-day town.

\section{Milorad Mladenović}

University of Belgrade - Faculty of Architecture 
Aleksandar Deroko had a noteworthy, if not a decisive impact on the architectural culture of Smederevo. This paper, however, will not treat the issue of his exceptional work on evaluating and protecting the medieval Smederevo Fortress, but rather it will focus on a very specific period during which Deroko, as an architect and a thinker, set up a significant number of parameters for a new vision for Smederevo's urban culture. This vision is embodied in his projects and architectural accomplishments in one of the most delicate periods of the town's history, during its reconstruction that lasted a few years after a horrific wartime explosion nearly wiped Smederevo off the map.

Following the incident, which took place on 5 June 1941, when an ammunition depot belonging to the German occupying forces exploded within the Smederevo Fortress, the town has often been referred to as the "Serbian Hiroshima". According to numerous reports and research on this tragic event, of which I will single out those conducted by Leontije Pavlović ${ }^{1}$ and Nebojša Jovanović, ${ }^{2}$ a definitive death toll has never been established, ranging between 1,500 and $4,000,{ }^{3}$ while ' 173 buildings were heavily destroyed, another 1,269 buildings severely damaged, and none remained intact. ${ }^{4}$ In his work, Jovanović quotes from the Smederevo Museum, which states: 'The commission tasked with assessing damages from the explosion concluded that of the overall number, there were only 25 undamaged buildings in Smederevo, while 1,331 buildings had varying degrees of damage and 149 were completely razed to the ground. ${ }^{5}$

Although a large number of works have been dedicated to the memory of this event and its analysis, as well as to the urban design and the reconstruction of Smederevo, a comprehensive historical and monographic assessment of this chapter in Serbian history from World War II has not been made to date due to widely differing ideologies and political motives. Consequently, neither has Deroko's entire body of architectural work in the aftermath of the explosion. His biographer Zoran M. Jovanović remarked that Deroko's 'work, which should be the most reliable indicator, has not been entirely catalogued', ${ }^{6}$ citing a statement by Slobodan Nenadović that Deroko would 'mention and attach great importance only to his most beloved completed projects' ${ }^{7}$ which has also contributed to the fact that his works have not been presented and examined in full.

This paper will attempt to bring to light some important issues relating to Deroko's work in Smederevo following the 1941 explosion, which have so far mostly been mentioned in passing either within the context of attempting to determine the historical circumstances that he witnessed and was part of, ${ }^{8}$ or 
within the context of attempting to catalogue his work. ${ }^{9}$ One of the topics deals with Deroko's relationship with the city's historical and cultural heritage, another to the political and ethical qualities of this relationship during a delicate period in Serbian history, and the third with the architectural and aesthetic principles that affected the way Deroko would shape his work in Smederevo, but also his vision for a rebuilt city. Lastly, this paper will hint at the qualifications of his work in Smederevo and its impact on the present-day town.

\section{I}

An important remark by Pavlović will be recorded in the annals of Smederevo, ${ }^{10}$ which explicitly explains Deroko's relationship with the town, he 'rushed and encountered a terrifying scene'. ${ }^{11}$ His immediate interest must have been colossal from a professional standpoint given that the explosion destroyed a sizeable portion of the fortress' outer wall on the south, while the possibility of an archeological investigation was considerably hindered by the mountains of rubble and craters within the medieval town. Nevertheless, it would be entirely wrong to view Deroko's relationship with Smederevo strictly through the lens of protecting this extraordinary cultural monument.

In his memoirs, ${ }^{12}$ Deroko recounts a significant event from his childhood when he visited Smederevo. Here he writes about a trip he made with his uncle Stevan Sremac ${ }^{13}$ with a 'simple boat' on the Danube River to Smederevo and back, particularly concentrating on the views along the riverbank and his impressions of his uncle's story about burials as they both watched a cemetery on a hill above Ritopek. Given that Deroko was investigative by nature and constantly made a record of what he saw there is no doubt that, already as a young man, he reflects on the nature-city settings of Smederevo, regarding them as the pinnacle of authenticism.

One of the most recognised Smederevo's features within the so-called trinity of its vineyards, the river, and next to the medieval fortress and the Church of the Assumption of the Mother of God perched on a hill on the western side of the outskirts of the town and whose dome can be clearly seen from the river, is the Golden Hill Villa, a one-time summer house of the Obrenović Dynasty, situated above a breathtaking vineyard on the northern hillside of Plavinac, only a few kilometers upstream from the fortress. Snežana Cvetković's monograph on this extraordinary monument also in part dedicates her research to Deroko's work in Smederevo. Her research can be seen as complementary of his work. ${ }^{14}$ 
Here I would like to stress the importance of this scenery so that I can confirm a belief that Deroko at a later stage, when he deliberated over the concept for Smederevo's reconstruction, certainly kept in mind its distinct and authentic character that defines the town both aesthetically and symbolically.

Prince Miloš Obrenović bought the estate covered by vineyards in Plavinac in the 1827-1829 period, which was followed by the construction of a wine cellar and a hostelry 'as a seed of an idea to build a summer palace in Smederevo'. He built a "Swiss style" summer house on the estate in $1865 .{ }^{15}$ Deroko will have the opportunity to see it as an exceptionally representative facility, whose adaptations was entrusted to a palace architect Jovan Ilkićl6 in 1897 by Queen Natalija. This summer house or "summer palace" of the Obrenović Dynasty will maintain the symbolic continuity of Smederevo's role as capital city with the fortified palace built by Djuradj Branković in 1430, and even with the seat of the Ruling Council of the Serbian Uprising between 1805 and 1807.

In the context of Smedrevo's comparative advantages of its particular climate and nature, vital production resources such as viticulture, fruit-growing, steelworks, and the monuments mentioned above, its close proximity to Belgrade will especially contribute to Smederevo being recognised as a major tourist and an excursion destination. These advantages will affect the development of the entire Danube riverbank along Smederevo, and the entire area, particularly along the river in Grocka, Brestovik, Orešac and Jugovo, will undergo a rapid development drive before WWII, turning them into destinations for excursions, weekend breaks and spa centres. The upper social class from Belgrade will be drawn here by the summer house of the Obrenović Dynasty and the vineyards along the Danube River, which will gradually transform Smederevo's residential areas of Jugovo and Plavinac into elite settlements, with rural houses set on vineyards replaced with villas and summer houses for the elite in the inter-war years. ${ }^{17}$ Their architecture will be defined by the interwar eclecticism.

Smederevo's defined character will affect the city's urban planning and development considerations, even during periods of significant historical revisionism. Immediately upon WWII breaking out in the territory of [former] Yugoslavia, when the town was nearly obliterated, it was necessary to rethink and shape its new urban and architectural identity in its entirety, with Deroko's work undoubtedly being instrumental in the process. Here, he acted as an architect with an acute sensitivity for a concept, which today we can identify as a form of regionalism in architecture. Above all, he will masterfully determine 
the scale of correlation between the three main features of the town to define the design and visual identity of the new town architecture: that between the heart of the town and the fortress, a distinctive urban structure marked by numerous squares in a relatively dense urban grid of the town centre, and taking into account its specific social aspects and production capacities I have already explained.

In his major work dealing with Smederevo ${ }^{18}$, Pavlović sharply criticises Deroko's approach to the reconstruction without specifically attributing responsibility for this to him. The reasons for this are evident today. Despite everything that implies criticism of Deroko, Pavlović will remark in his piece on Deroko's death, 'Deroko is the most significant and extraordinary figure who has managed to tie himself to Smederevo even after his death. ${ }^{19}$

I I

If we want to determine the ethical context of Deroko's work following the Smederevo explosion on 5 June 1941, from the outset we are faced with the possibility that his involvement can be seen as explicitly reactive, and thereafter it can be considered from two important points: a political context in which he was engaged in the post-explosion reconstruction project and through understanding the ethical and aesthetic identity which he projects through his architecture in the years of reconstruction.

It is well-known from numerous literary works that Dimitrije Ljotić, with all the required consent, was at the helm of the Extraordinary Commissariat for Smederevo's reconstruction, which was already set up in early July 1941 by the Council of Commissaries (or the so-called "commissioner administration"). The aforementioned work by Jovanović ${ }^{20}$ represents the most general overview of archival materials on the activities of the Extraordinary Commissariat held by the Historical Archives in Smederevo. Here it is significant to point out that, 'Ljotić received the green light to make changes to the approved general plan of Smedrevo ${ }^{21}$ under shortened procedure' and 'the Reconstruction Fund was set up', ${ }^{22}$ all of which implies that the Extraordinary Commissariat had no intention to only launch a reconstruction effort for the demolished town and to provide accommodation for those affected by the explosion, but also to conceive a new urban structure ${ }^{23}$ on its ruins. To this end, and as a basis for reconstruction, an architectural bureau was formed as part of the Commissariat, which was located in the building of the Smederevo Endowment from 1 September 1941. 
Mihajlo Radovanović, a professor of urbanism at the Faculty of Architecture in Belgrade, was appointed as the head of the bureau. He is also one of the founders of urban planning and Deroko's colleage from the faculty. ${ }^{24}$

It must be pointed out that it is not possible to explain Deroko's role in rebuilding Smederevo outside the known circumstances of his arrest and detention at the Banjica concentration camp, ${ }^{25}$ where he was placed in November 1941, spending 'three difficult and uncertain weeks'. In his memoirs, Deroko sheds light on a number of important points, firstly that his name was not on 'a list of signatories obtained under duress by Ljotić's people and Jonić's “education ministry", which would exempt him from being arrested but rather on a list of 'selected unruly intellectuals'. In his description of the list compiled after communists were denounced, Deroko stresses that 'a pretext for the list were the masons', and that it was put together with the help of a 'confidential German book'. After 'Hitler abandoned the idea of mass shooting', in Deroko's words, '[they] resorted to blackmail', after which 'half of detainees were gradually released' ${ }^{26}$

According to Jovanović, 'Smederevo's new regulation and building plan in line with the modern urban planning principles was made available to the public between 4 and 8 September 1941 at the Town Hall.' In his description of the design plan for an urban block located between the Kralja Petra street and the fortress, which envisaged 140 multi-storey buildings and 90 single-storey buildings with the capacity to house 2,600 residents, Jovanović mentions that 'some of the buildings on the block, with stylish fences, paths lined with trees and green spaces were designed by architect Aleksandar Deroko' ${ }^{27}$ All of this does not suggest that Deroko took part in devising the regulation and building plan, but it is very likely that he was familiarised with it before his detention given that university professors Mihajlo Radovanović, Svetozar Jovanović and Momir Korunović ${ }^{28}$ participated in the reconstruction. However, it is possible that his involvement had been planned. We can assume that Deroko was released from the Banjica concentration camp in November 1941 so that his expertise and knowledge could be used in reconstruction activities led by the Extraordinary Commissariat. Considering that his project on the Memorial Ossuary, which he designed 'at the invitation of the Extraordinary Commissariat [...] was deliberated and adopted at a session of the Commissariat's advisory board in March 1942', ${ }^{29}$ it is clear that he started working on it immediately upon his release from the concentration camp. It is difficult to imagine that Ljotic was unaware of Deroko's liberalism and freemasonry, had this been the reason for his arrest. The more probable explanation for his engagement in the Memorial 


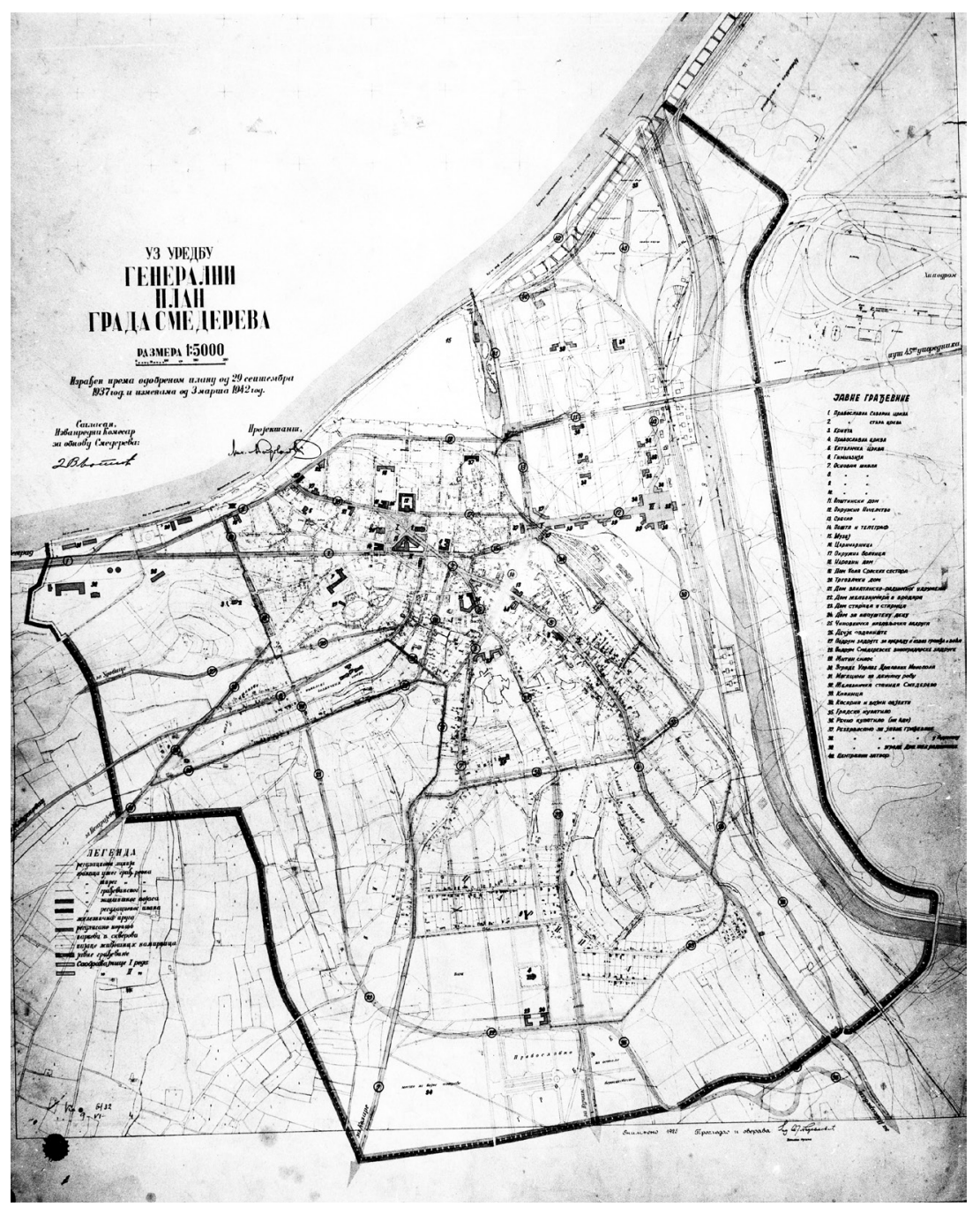

Fig. 1. Mihajlo Radovanović's general plan for Smederevo from 3 March 1942 (with a notice that it was developed based on the approved plan from 29 September 1937) shows the concept of the town renewal with a view to the rationalisation of the urban structure, especially in the area between Kralja Petra and Vuk Karadzic streets and the accessable outer wall of the Smederevo Fortress on the south, which completely abandons the existing street grid and introduces an orthogonal street layout. The plan document is being held in the Directorate for Construction, Urban Planning and Building Land of Smederevo. 
Ossuary project is Deroko's previous experience in designing these type of facilities $^{30}$ and his knowledge of the national architecture and monuments. Starting with the Memorial Ossuary, his role would expand to cover a string of other design activities during Smederevo's reconstruction.

Deroko's work, as much as it arises from his awareness and love of national culture on the whole, and as such could have made an impression on Ljotić, cannot be interpreted as an act of reconciliation with any form of the Nazi ideology. He said way back in 1925 that 'chauvinism can only be bad for the science and critique of art, and acknowledging the truth and the affairs of others, we can rightfully be proud of what remains exclusively ours, which is by no means negligible'. ${ }^{31}$ This statement defines his artistic and ideological vantage point. Deroko's religious beliefs, which are also significant within this context, can be easily discerned from the voluminous descriptions in his memoirs about the travels with Rastko Petrović, which show his very rational and investigative approach to the importance of church and religion. It is not devoid of respect and love, but primarily concerned with the aesthetic phenomenon of their significance. With regard to his take on art, his indictive conversation with Moma Dimić in 1981 clearly reflects his complex attitude towards modernism, which, in turn, hints at a preference for a specific approach to the influence of folklore and the national heritage on architecture, but also to the impact that modernism has on this aesthetic concept of architecture. ${ }^{32}$ In it, for example, Deroko criticised Le Corbusier's concept of architecture as inhumane, while highlighting the 'usefulness' of dadaism or 'contributions' made by Pablo Picasso and Henry Moore. It is hard to believe that such attitudes by Deroko can conceal unbridled conservatism or nationalism, which are often attributed to his instructing parties in Smederevo's post-explosion reconstruction.

Pavlović's critique in a chapter entitled "The Status of Urbanism During the Occupation" 33 hints at where danger could lie in Deroko's aesthetic approach to Smederevo's reconstruction. He writes, without specifically attributing responsibility to him:

'Here, for example, Smederevo was envisioned as a provincial town comprising a typical centre and periphery, whose residents would work in retail, diligently till the vineyards and export wines to Germany. While under Ljotić construction work is taking place in Smederevo, all other parts of our country are being set on fire and ravaged. From mid1941 through to the end of 1943, 115 buildings were built in Smederevo, of which 80 are multi-storey and 35 single-storey buildings. Most of them have been built in the "Serbian national style". The buildings are 
made of brick and reinforced concrete, with added elements of Serbian folk architecture based on a timber-framed system (post and pan). Reminiscent of colonial rule, these type of buildings with their vibrant colours were built to divert attention from real issues and attempt to keep alive the spirit of national feeling, preventing people to look ahead. To this end, people were encouraged to look to the past, while national aspirations were reduced to provincial romanticism. ${ }^{34}$

\section{I I}

Casting a critical eye on Deroko's work in Smederevo today, Pavlović's qualifications appear to be obscure primarily due to their inability to qualify this architecture as an expression of petit bourgois ideologies, privacy and nationalist romanticism. It is worth bearing in mind that the planned and partially built complex of the block between the Kralja Petra street and the fortress was designed in the spirit of a rational, modern town, with a strong collective and social structure. Plans designed by Mihajlo Radovanović ${ }^{35}$ correspond to the modern concept of a town, combined with building rows, which form the edge with free-standing apartment buildings within a regular and rationalised urban grid of the town. Thus, these design plans go beyond the traditional model of a provincial town. Deroko's contribution to these plans mainly deals with the design process of individual facilities and urban street furniture. His interventions on Radovanović's rationalised structure add colour to the form of these facilities with elements such as oriel windows, porches and terraces, elevated attachment corners, protruding chimneys and eaves, none of which interfere with the urban grid of the town and its composition. These architectural elements are actually rationalised and simplified and repeated in different ways from one facility to another. In this manner, Deroko makes a visible distinction between them, while on the whole, they maintain a unique aesthetic experience of the new town and its specific identity. It must also be acknowledged that in time of war, due to the urgency for reconstruction and the obvious shortage of funds, Deroko does not attempt to build complex or exhibitionist structures, but still manages to add an effective playfulness to them and to provide a distinctive experience of the town. ${ }^{36}$

It appears that these very circumstances worked in Deroko's favour, enabling him to strike a brilliant balance between formal modernism and distinctive and recognisable, yet functional folklore elements, and thanks to these solutions, to reach one of his creative peaks, especially in terms of his specific and, in 
fact, the most representative work in architectural design before WWII. ${ }^{37}$ From today's perspective, "Deroko's houses"38 can be seen as classic illustrations of what we today call postmodernism in architecture. In this sense, Deroko's work comes across as an "objective anticipation".

Almost all professional publications describe his work in Smederevo strictly in terms of "folklore architecture", the "Serbian national style", "national romanticism", etc. Such generalisations do not provide deeper analysis of his architectural creations, but these constructed and preserved structures cannot only be interpreted as such, as much as these qualifications are to a greater degree acceptable. It would be most interesting to make a comparative study of Deroko's work with Frank L. Wright's organic architecture, as opposed to the comparison with Le Corbusier's "inhumane" concept. The analysis would beyond doubt point to significant similarities in their treatment of architectural composition and aesthetics. The parallels can be drawn in elements such as low-angle roofs with eaves over clear cubic geometry and a multitude of details, particularly corner windows $\mathrm{s}^{39}$, as well as significantly larger window openings compared to those typical of folklore architecture.

Collective housing projects designed by Deroko display features of urban architecture, with luxury period-inspired flats that have a pronounced openness and connection with the immediate environment of the town. Some of these buildings are designed with typical modern longitudinal terraces, behind which are vertically slanted walls with generously big glass openings in typical modern horizontal division sense. These type of details are absent in folklore architecture.

We can see the specific quality of Deroko's interventions within the context of Radovanović's new urban plan, which in a new way define the town centre's relationship with the fortress and the area covering the town's northwestern zone along the Despota Djurdja street in the direction of the Danube River. The plan envisages building a square in the adjacent zone of the town centre and the fortress, which has been backed with a plan to relocate Smederevo's railway station that interrupts the continuity between the main square in central Smederevo and the fortress. With this move, the city would practically and flawlessly be opened and oriented towards the fortress, as its central monument, and towards the Danube River, as its most valuable natural resource. All architectural projects implemented during Smederevo's reconstruction, and especially those that were conducted by Deroko, are led by this newlyestablished orientation. In this sense, "Deroko's houses" have entrances facing 
Fig. 2. National state school Kralj Petar II (today Dimitrije Davidović Elementary School) is Deroko's (with architect Milenko Radovanović) most complex building to have been built during Smederevo's reconstruction in 1943.
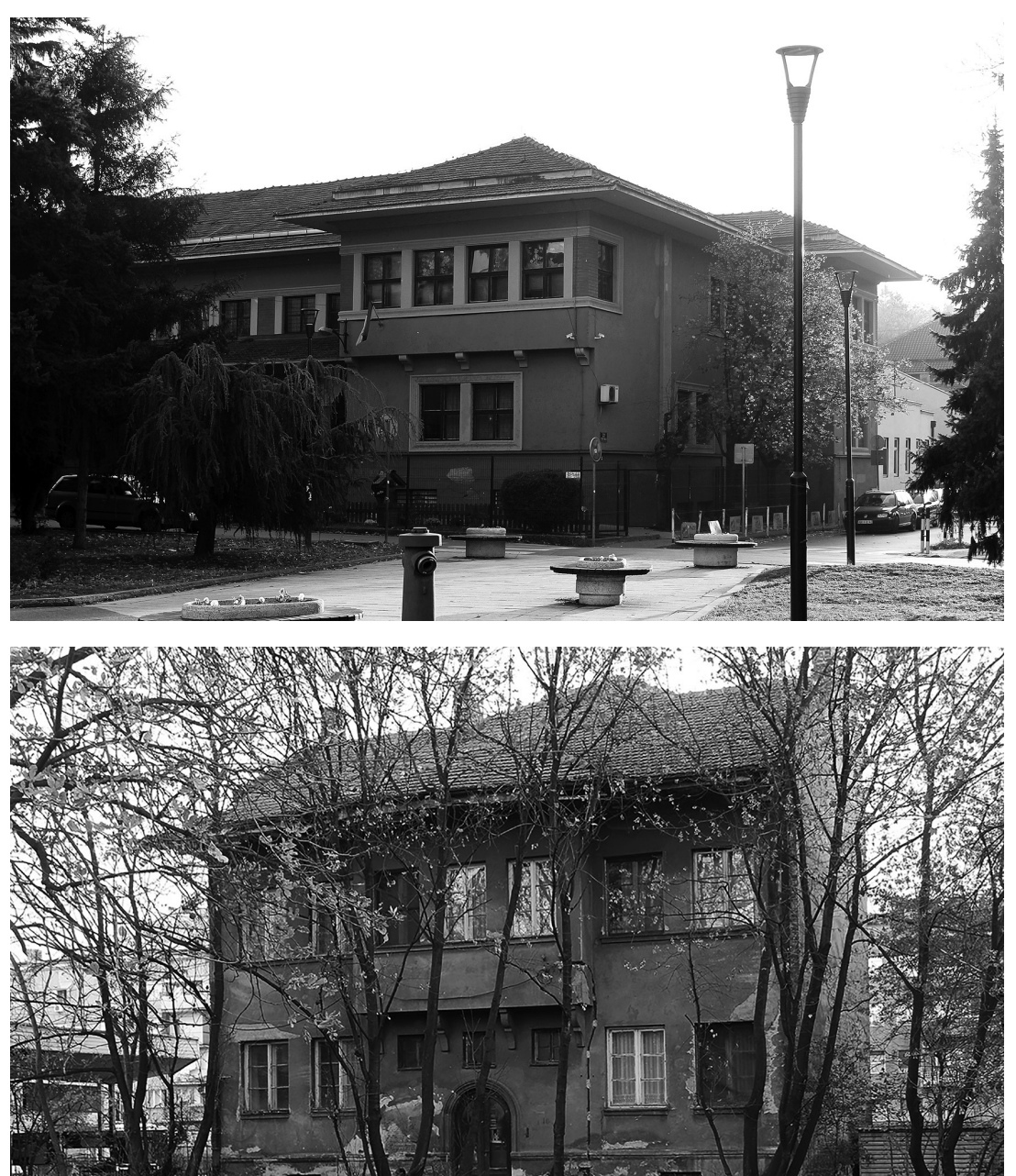

Fig. 3. Park House in Omladinska street in Smederevo in the immediate vicinity of the Smederevo Fortress, overlooking its outer wall on the south. On the left there is the Lasta Bus Station built after WWII, and on the right the Smederevo Museum designed during the Smederevo's reconstruction as is the Hotel Jadran. The house is designed as part of the building rows of the block from 1942 orientated toward the Fortress. 
the fortress, enforcing the concept of city centre gravitating towards it. A relatively small number of Deroko's facilities built within this zone actually underline this concept. However, through an analysis of their spatial planning we can discern the conceptualised urban intentions and how these facilities are precisely located with respect to this plan. Along with the orientation of entrances, this concept can be recognised in the disposition of balconies and oriel windows by which residential units within these buildings are fully adapted to face the fortress.

In his book Istorija Smedereva u reci i slici [History of Smederevo in words and pictures], Pavlović unjustifiably criticises this concept, claiming that 'the buildings, which have been placed in the lower section of the town close to the fortress, are unacceptable because they block the view of the fortress' ${ }^{40}$ Facilities erected during Smederevo's reconstruction, in terms of their volume and height, the manner in which they were built, and particularly in terms of their design, to this day demonstrate Deroko's understanding of the importance of national heritage, its activation and its development potential within the complex treatment of a modern town. Without a shadow of doubt, he regarded Smederevo, above all else, as inextricably aesthetic and symbolic unity of the town and its most prized monument - the fortress.

$\star \star \star *$

Urban planning and construction of Smederevo will be areas that will develop with astonishing pace and varying quality after WWII, but it will not relate to reconstruction parameters in which Deroko took part after the 1941 explosion in Smederevo. The socialist era of construction in Smederevo is characterised by a reverse orientation and the development of urban areas further away from the fortress. This development will undermine the significance and an exceptional location of the fortress despite substantial investments in its reconstruction and maintenance, and persistent awareness that it is an irreplaceable cultural resource in Smederevo. Deroko was troubled by this and, in this sense, remained present in Smederevo until the end of his life. Regardless of this, there were insufficient practical solutions as to how urbanisation of the town should be tackled with respect to the fortress. Other vital resources, such as securing links between the city centre and the surrounding riverbank areas, would face a similar fate. Despite being a recurring topic of debates, solutions would be modest, all too often impractical and sometimes outright inadequate. 
It is understandable that the rapid growth of the town after the war called for extensive construction works outside the protected zone of the Smederevo Fortress, thereby creating relatively remote and differently oriented urban centres. It is also understandable that this development embraced the architecture of socialist aestheticism. Pavlović himself observed misplaced activities is these concepts despite indirectly criticising Deroko's work. ${ }^{41}$ It seems almost incredible that critical issues in urban planning of Smederevo's centre remain unresolved even 45 years after socialism and nearly 30 years of postsocialism: primarily, the disruptive location of Smederevo's main railway and bus station, but also a cluster of inadequate facilities located in close proximity to the adjacent zone of the town centre and the fortress. ${ }^{42}$ The river port created in the city centre itself has made the access to the river more difficult, and with it, the link between the fortress and the river remains inadequately resolved to this day. Although it is understandable that plans for the town which has grown considerably in size cannot be consistent with the concepts and capacities defined by Radovanović during Smederevo's reconstruction between 1941 and 1943, where Deroko played a significant role in providing direction in architectural design and urban details, it can be argued that efforts should have been made to maintain its concept, modesty and quality, at least in the adjacent zone of the town centre and the fortress.

Hiding in plain sight, a keen observer will today recognise Deroko's vision for the new Smederevo in the many fragments within its centre, while those with imaginative flair can use these fragments to compose the most convincing picture of the new town built around the medieval fortress of Serbia's temporary capital in the Middle Ages. 
Nebojša Jovanović, Smederevo je bilo dobro obnovljeno: Dimitrije Ljotić i delatnost Izvanrednog komesarijata 1941-1944 (Smederevo: Deni Graf, 2011).

The only certain death toll from the explosion is given on the list of names on the Memorial Ossuary in Smederevo designed by Deroko. However, it should be noted that a large number of its inhabitants, particularly those from the villages in the vicinity of Smederevo, and a large number of visitors to the city, were not buried here. Leontije Pavlović, Istorija Smedereva u reči i slici (Smederevo: Muzej u Smederevu, 1980), 374. Museum in Smederevo, Archive no. 1040/69.

Zoran M. Jovanović, Aleksandar Deroko (Beograd: Republički zavod za zaštitu spomenika kulture, Društvo konzervatora Srbije, 1991), 63.

Deroko's attitude to the work on rebuilding Smederevo was influenced by two relevant issues: the fact that he often collaborated and had an unofficial role in the implementation of these projects and the specific "political context of their implementation". 
The works by Pavlović and Jovanović mentioned in the above notes.

See the work of special importance: Vesna Mrkić, "Pokušaj rasvetljavanja uloge Aleksandra Deroka u obnovi Smedereva tokom Drugog svetskog rata," Glasnik društva konzervatora Srbije 33 (2009): 157-163.

Leontije Pavlović, Smederevo i Deroko (Smederevo No. 3 and No. 4, 1997).

There is no available information about when this event exactly took place, but it can be concluded from the statement that it preceeded Deroko's involvement in the activities of the Extraordinary Commissariat for Smederevo's reconstruction. The Commissariat itself was set up very quickly after the explosion, suggesting that Deroko visited Smederevo prior to his arrest in November. He starts working on the project to build the Memorial Ossuary upon his release from the Banjica concentration camp. Deroko's letter to Dimitrije Ljotić dated 29 March 1942 gives an account of his work on it as in it he gives certain recommendations regarding the beginning of works on this project. The letter was published in full in the above mentioned work by Jovanović.

Aleksandar Deroko, A ondak je letijo jeroplan nad Beogradom, $3^{\text {rd }}$ extended edn, Biblioteka Grifon (Belgrade: Narodna Knjiga, 1987), 135-136.

Stevan Sremac was a Serbian realist and comedy writer, considered one of the best truly humorous Serbian writers.

Snežana A. Cvetković, Vila dinastije Obrenović, $2^{\text {nd }}$ revised and extended edn (Smederevo: Muzej u Smederevu, 2012). See also her other work: “ДDerokove kuće / Izgradnja Smedereva u II Svetskom ratu," Smederevska sedmica (6.12.2002): 16-17, and "Peti jun 1941. godine u spomeničkom nasledju Smedereva," Mons Aureus 53 (2016): 131-137.

Ibid., 11.

Ibid, 70. At the request of King Milan Obrenović, Ilkić arrives from Vienna to complete renovation works on the Old Palace in Belgrade. He also designed the National Assembly, originally the House of National Representation until 1903.

To a lesser extent, areas along the Danube River in Smederevo have similar development characteristics to that of Belgrade's Dedinje suburb.

Leontije Pavlović, Istorija Smedereva u reči i slici (Smederevo: Muzej u Smederevu, 1980), 374375.

Leontije Pavlović, "Spasitelj Smederevske tvrđave (nedavno preminuli akademik ostavio u Smederevu dubok trag)," Glas (27.12.1988): 7.

Nebojša Jovanović, Smederevo je bilo dobro obnovljeno: Dimitrije Ljotić i delatnost Izvanrednog komesarijata 1941-1944 (Smederevo: Deni Graf, 2011). Jovanović gives intricate details of the Extraordinary Commissariat's activities (from the page 49).

This is the master plan from 1937 which was the basis for changes in 1942.

Nebojša Jovanović, Smederevo je bilo dobro obnovljeno, 51.

Ibid., 52, quoted Dimitrije Najdanović from the Naša Borba newspaper, 14 June 1943: 'The catastrophe in Smederevo is a watershed moment for architectural renaissance in the country.'

Ibid., 152, giving a list of the Architectural Bureau's members.

Sima Begović, Profesori akademici u logoru na Banjici, zbornik radova Univerzitet u Beogradu 1838-1988 (Belgrade: Univerzitet u Beogradu, 1988), 245, 261.

Aleksandar Deroko, A ondak je letijo jeroplan nad Beogradom, 111-112.

Nebojša Jovanović, Smederevo je bilo dobro obnovljeno, 74. Please see the archival document AS-IK 90/41.

Vesna Mrkić, "Pokušaj rasvetljavanja uloge Aleksandra Deroka u obnovi Smedereva tokom Drugog svetskog rata," 157. 
Nebojša Jovanović, Smederevo je bilo dobro obnovljeno, 42: 'The work on erecting the monument started with the commencement date for Milivoje Antonić, a contractor from Požarevac, on 17 March 1942.'

Snežana A. Cvetković, "Peti jun 1941. godine u spomeničkom nasledju Smedereva," Mons Aureus 53 (2016): 131-137: 'Before the construction of the Memorial Ossuary with a bell tower in Smederevo, Deroko's approach to monuments, memorials and funerary architecture was depicted in his design of a bell tower of the Church of St. Demetrius in Bitola, Macedonia (1930), the Memorial ossuary to fallen assassins in Sarajevo, Bosnia-Herzegovina (1939), a competition project to build a memorial ossuary on the Greek island of Vido (1925), the memorial chapel at the Zeitenlik cemetery in Thessaloniki, Greece (1926), and a tombstone of Duke Radomir Putnik in Belgrade, Serbia (1927).'

Aleksandar Deroko, “Jedna potrebna orijentacija u našoj umetnosti,” Pokret, 43-46 (1925): 300304.

Moma Dimić, "Kuće i drugi neimarski dani," The Gradina Journal no. 8-9 (1981). The text was published as a supplement in Deroko's book A ondak je letijo jeroplan nad Beogradom, 315.

Ibid.

Radovanović's general plan for Smederevo from 3 March 1942 (with a notice that it was developed based on the approved plan from 29 September 1937) shows the concept of the town renewal with a view to the rationalisation of the urban structure, especially in the area between Kralja Petra and Vuk Karadžić streets and the accessable outer wall of the Smederevo Fortress on the south, which completely abandons the existing street infrastructure/grid and introduces an orthogonal street layout. The concept for a square in the adjacent zone of the town centre and its fortress is particularly significant, with Deroko articulating architecture for certain facilities in relation to it. Radovanović's plan is filed with the Directorate for construction and urban planning in Smederevo.

This flies in the face of Pavlović's observations in Istorija Smedereva $u$ reči $i$ slici, where he disapproves of the costly constructed facilities and the municipality's over-indebtedness at the time of the Extraordinary Commissariat's operations. Nevertheless, it must be pointed out that "Deroko's houses" were truly not expensive. They were conceptualised as collective housing when Smederevo had only 11,000 inhabitants, whereas its urban population has grown five-fold by the time Pavlović addressed the issue. This development could not have been foreseen when Radovanović drafted the plan in 1942 .

Deroko realised the majority of his important architectural projects before WWII, of which those that were carried out in Smederevo, particularly residential architecture, were considerably more modest. Please see the catogalisation in Zoran M. Jovanović, Aleksandar Deroko, 110-113.

The term "Deroko's houses" is a colloquial expression used widely for a wide range of facilities built in Smederevo in the post-explosion period in WWII.

National state school Kralj Petar II, which is today named Dimitrije Davidović Elementary School, is Deroko's most complex building to have been built during Smederevo's reconstruction in 1943. The building, designed with architect Milenko Radovanović, boasts well-executed details mentioned in the text and a visual quality.

He adds that 'apart from this, a provincial town structure has long existed further away from the fortress, which came about spontaneously,' Leontije Pavlović, Istorija Smedereva u reči i slici, 375.

'We propose that skyscrapers be designed in the most humane manner possible, so that there would some type of connection with houses and the fortress [...] Environmental and accommodation surroundings should be more humane, attractive and warm. This type of architecture alienates one from life's destiny,' Леонтије Павловић, Историја Смедерева у речи и слици, see: Chapter "Urban Development in Socialist Era" from page 426, the section A) Reviews and Observations. 
Some facilities, such as warehouses, in close proximity to the Smederevo Fortress, instead of being removed, have been converted to hypermarkets in recent years, which shows a tendency towards regression in the urban culture of the town. The construction of the new main bus station envisaged by the general plan for Smederevo, which dates back to 1985, has not begun despite the fact that preparatory works on a location in Godomin were completed in the early 1990s. Recent activities related to the construction of a dock show that there are plans to beef up Smederevo's tourism potential, which are not defined through the strategic urban planning concepts. Considering all of the above, restrospection on Deroko's activities becomes that much more significant. Godomin. 
Begović, S. Profesori akademici u logoru na Banjici, zbornik radova Univerzitet u Beogradu 18381988. Beograd: Univerzitet u Beogradu, 1988.

Deroko, A. A ondak je letijo jeroplan nad Beogradom ( $3^{\text {rd }}$ extended edn, Biblioteka Grifon). Beograd: Narodna knjiga, 1987.

Deroko, A. "Jedna potrebna orjentacija u našoj staroj umetnosti." Pokret 43-46 (1925).

Dimić, M. "Kuće i drugi neimarski dani." Gradina no. 8-9 (1981).

Jovanović, M. Z. Aleksandar Deroko, Posebna izdanja 8. Beograd: Republički zavod zaštitu spomenika kulture, Društvo konzervatora Srbije, 1991.

Jovanović, N. Smederevo je bilo dobro obnovljeno: Dimitrije Ljotić i delatnost Izvanrednog komesarijata 1941-1944. Smederevo: Deni Graf, 2011.

Mrkić, V. "Pokušaj rasvetljavanja uloge Aleksandra Deroka u obnovi Smedereva tokom Drugog svetskog rata." Glasnik društva konzervatora Srbije no. 33 (2009).

Pavlović, L. Istorija Smedereva u reči i slici. Smederevo: Muzej u Smederevu, 1980.

Pavlović, L. "Spasitelj Smederevske tvrđave (nedavno preinuli akademik ostavio u Smederevu dubok trag)." Глас (27. XII 1988).

Cvetković, A. S.. "Peti jun 1941. godine u spomeničkom nasleđu Smedereva." Mons Aureus 53 (2016).

Cvetković, A. S. Vila dinastije Obrenović u Smederevu ( $2^{\text {nd }}$ revised and extended edn). Smederevo: Muzej u Smederevu, 2012. 